\title{
Evaluation of Growth Parameters and Germination Behaviour of Different Tomato (Lycopersicon esculentum Mill.) Cultivars under Hydroponic Condition
}

\section{Mehwish Liaquat $^{1 *}$, Arshad Mahmood Malik ${ }^{1}$, Muhammad Ishaq ${ }^{1}$, Hafiz Muhammad Qasim Ashraf $^{2}$ and Ismara Naseem ${ }^{1}$}

${ }^{1}$ Institute of Hydroponic Agriculture, PMAS Arid Agriculture University, Rawalpindi, Pakistan; ${ }^{2}$ Institute of Horticultural Sciences, University of Agriculture Faisalabad, Pakistan.

\begin{abstract}
Tomato (Lycopersicon esculentum L.) is an important vegetable crop of Pakistan. Tomato is most edible and nutritious vegetable crop. The study was performed at the Institute of Hydroponic Agriculture PMAS Arid Agriculture University Rawalpindi to check the growth and germination behaviour of different tomato (Lycopersicon esculentum L.) varieties grown under hydroponic conditions. Five different tomato varieties (Berberana F1, Lezaforta F1, Elipida F1, Premium Ruby and Cherry Tomato) were used for the experiment. Growth related parameters such as shoot length, root length; stem diameter and number of leaves were observed at 30 days aged seedlings in coco peat media. The experiment was executed according to completely randomized design (CRD) with four replications. Analysis of variance (ANOVA) was performed on the data. Significant changes were observed in growth parameters among different tomato varieties. Data were collected on germination percentage after two days interval. The results revealed that the germination percentage (100\%) was higher in Cherry Tomato. The seedling root length $(37.62 \mathrm{~mm})$, seedlings shoot length $(89 \mathrm{~mm})$, number of leaves $(6)$, stem diameter $(1.74 \mathrm{~mm})$ were observed in Berberana tomato variety than the other varieties and therefore it is found that tomato varieties such as Cherry and Berberana in hydroponics system can use for good seedling quality and germination behaviour.

Received | January 14, 2020; Accepted | June 23, 2020; Published | August 01, 2020

*Correspondence | Mehwish Liaquat, Institute of Hydroponic Agriculture, PMAS Arid Agriculture University, Rawalpindi, Pakistan; Email: mehwish2454@yahoo.com

Citation | Liaquat, M., A.M. Malik, M. Ishaq, H.M.Q.Ashraf and I. Naseem. 2020. Evaluation of growth parameters and germination behaviour of different tomato (Lycopersicon esculentum Mill.) cultivars under hydroponic condition. Pakistan Journal of Agricultural Research, 33(3): 544-549. DOI | http://dx.doi.org/10.17582/journal.pjar/2020/33.3.544.549

Keywords | Growth, Germination, Hydroponic, Seedling variables, Tomato, Varieties
\end{abstract}

\section{Introduction}

$\mathrm{T}$ omato (Lycopersicon esculentum L.) is one of the most important vegetable crops of Pakistan. Tomato is most edible and nutritious vegetable and widely grown in regions such as tropical, subtropical and temperate environments worldwide due to their widespread acceptance and compensating prices in the market. Tomato is the most consumed, profitable and popular vegetable for producer in the world
(Fernandes et al., 2007; Nasir et al., 2015). Tomato is a rich source of protein and carbohydrates (Perveen et al., 2015), play significant functions in human diet and provide well-balanced essential nutrients (Ilahy et al., 2016). However, tomato contain large amount of total antioxidant, total phenolic contents, ascorbic acid and carotenoids (Vinha et al., 2014).

Varietal selection is the major factor for healthy seedling along with better production and quality of September 2020 | Volume 33 | Issue 3 | Page 544 
tomato and its vigor. Seed germination is a critical stage because the entire plant lifespan depends directly on the germination rate (Qadir and Shahzadi, 1969). The higher growth parameters (root length, shoot length, stem thickness and number of leaves) were found at 30 days aged seedlings in coir pith media (Vivk and Duraisamy, 2017). Growth media have significant effect on flowering plants and play a vital role in rate of germination and many growth-related parameters such as plant height, leaf number, leaf length, stem girth and yield etc. (Vendrame et al., 2005).

Protrays are currently used for rising most of the vegetables seed in hydroponic system as compared to traditional nursery bed. The seedlings raised in the protray are germinate quickly and healthy. Seed sown in protray showed better root development and reduce mortality rate. Seeds sowing are done manually in protarys. The protray plugs are properly filled with a media and finally transplanted into growth chamber. Single seed is put in one cell of protray plug. The plants grown in protray enhanced transplanting efficiency and provide a better supply of good quality seedlings (Jeong, 1992).

Cocopeat is an organic matter used as plant growing media which are prepared from coconut husk also known as coconut coir. It is an essential growing media in horticulture plant nurseries. Cocopeat is by-product of agriculture obtained by extracting fiber from coconut shell (Abad et al., 2002). Cocopeat as a hydroponic growing media can be used to produce a large quantity of horticultural crops with adequate quality in the tropics (Yahya and Mohklas, 1999; Yau and Murphy, 2000). Abad et al. (2002) reported that cocopeat is a good growing and rooting media with high water holding capacity, acceptable $\mathrm{pH}$ and EC, good aeration, low shrinkage, less bulk density and increase shelf life of the plants (Evans et al., 1996; Prasad, 1997).

Little research has been reported on these tomato cultivars evaluation especially in temperature controlled glasshouses and hydroponic system in Pakistan. The present research work aimed to check the growth and germination behaviour of different tomato varieties grown under hydroponic system.

\section{Materials and Methods}

The study site, Institute of Hydroponic Agriculture PMAS Arid Agriculture University Rawalpindi. Five different tomato varieties (Berberana F1, Lezaforta F1, Elipida F1, Premium Ruby and Cherry Tomato) were used for the experiment. The well decomposed coco peat was used as media for raising the tomato seedlings. The media was filled half of each cell in the tray. Single seed was kept in each cell an inch deep of the protray (Figure 1) and covered all seed plug on the top with cocopeat. Seeds were sown in trays in the germination room which was maintained at $25^{\circ} \mathrm{C}$ temperature and $95 \%$ relative humidity $(\mathrm{RH})$. The temperature was recorded on daily bases the average maximum and minimum temperatures of $33.4^{\circ} \mathrm{C}$ and $15.3^{\circ} \mathrm{C}$ and average maximum and minimum R.H. of $90 \%$ and $40 \%$ respectively. The protray was completely covered with polythene sheets to keep them moist. The seed start sprouting within 4 to 5 days with two or three leaves and regularly water application was increased depending on moisture level in protarys (Figure 2). At the end of $14^{\text {th }}$ day of germination test, the number of normal seedlings in each tray was counted and germination was calculated at two days interval and expressed in percentage (Figure 3). Simultaneously, germination per cent of seedlings were calculated using the following formula (Atif et al., 2016).

$$
\text { Germination } \%=\frac{\text { Seed germinated }}{\text { Total No of seeds }} \times 100
$$

After 30 days, the growth parameters i.e., leaf number, shoot length $(\mathrm{mm})$, root length $(\mathrm{mm})$ and stem girth $(\mathrm{mm})$ were calculated (Table 2$)$. The seedlings were removed manually from the protray cells. The seedling root and shoot length was noted with a steel rule with least count of $0.5 \mathrm{~mm}$. The stem girth was calculated by using a digital vernier caliper with least count of $0.02 \mathrm{~mm}$. The measurements were taken after 30 days old tomato seedlings. Brief description of tomato cultivars are described in Table 1.

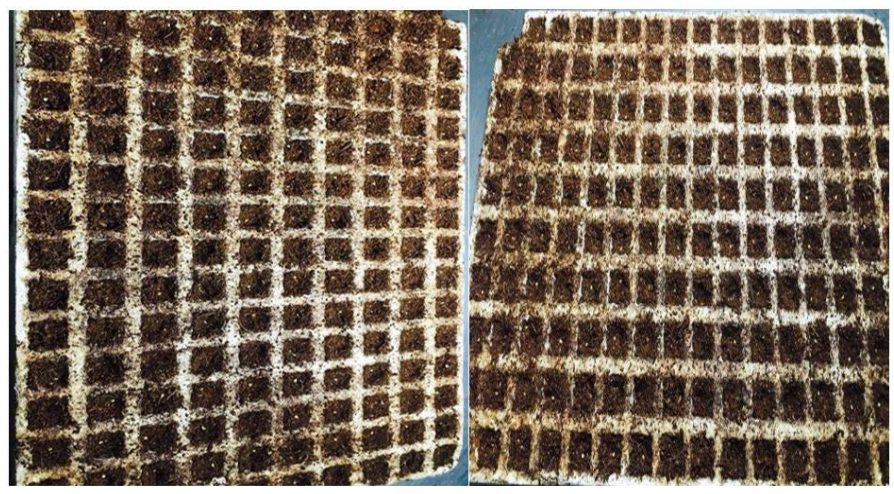

Figure 1: Tomato seed grown in protray with coco peat media. 
Table 1: Tomato cultivars description used in the experiment.

\begin{tabular}{|c|c|c|c|c|}
\hline Varieties & $\begin{array}{l}\text { Growth } \\
\text { habit }\end{array}$ & Unique character & $\begin{array}{l}\text { Seedling } \\
\text { emergence }\end{array}$ & $\begin{array}{l}\text { Maturity } \\
\text { days }\end{array}$ \\
\hline Berberana F1 & $\begin{array}{l}\text { Indeter- } \\
\text { minate }\end{array}$ & $\begin{array}{l}\text { It is a very large beef tomato variety, vegetative with a good force of growth } \\
\text { Development of brushes, uniform throughout all vegetation, roundish mass } \\
\text { of a fruit } 250-280 \mathrm{~g} \text { Color of a fruit: bright red }\end{array}$ & 5 to 12 days & 95-105 days \\
\hline Lezaforta F1 & $\begin{array}{l}\text { Indeter- } \\
\text { minate }\end{array}$ & $\begin{array}{l}\text { beef tomato, fruits are larger in size, fruit weight } 220-250 \text { g; High yielding } \\
\text { variety }\end{array}$ & & 100 days \\
\hline Elipida F1 & $\begin{array}{l}\text { Indeter- } \\
\text { minate }\end{array}$ & $\begin{array}{l}\text { Beef tomato, Market leader throughout the world } \\
\text { Low-maintenance hybrid. Strong plant with short internode. Good resist- } \\
\text { ance to temperature drops. } \\
\text { Uniform large round fruits of bright red color, weight of fruit 200-230 g. } \\
\text { High quality fruits with good shelf life }\end{array}$ & 14 days & 80 days \\
\hline $\begin{array}{l}\text { Premium } \\
\text { Ruby }\end{array}$ & $\begin{array}{l}\text { Indeter- } \\
\text { minate }\end{array}$ & Outstanding flavour and colour and high yield potential, high sugar contents & 5 to 14 days & $\begin{array}{l}\text { Medium } \\
\text { early } 70 \text { days }\end{array}$ \\
\hline $\begin{array}{l}\text { Mimi Cherry } \\
\text { Tomato }\end{array}$ & $\begin{array}{l}\text { Indeter- } \\
\text { minate }\end{array}$ & $\begin{array}{l}\text { Good productivity and excellent flavour and has high commercial value. } \\
\text { Cherry tomatoes are small and brightly colored. They are generally red or yel- } \\
\text { low flavorsome, sweet and sometimes slightly sour, fresh and crisp }\end{array}$ & & 65 to 70 days \\
\hline
\end{tabular}

\section{Statistical analysis}

The study was planned according to completely randomized design (CRD). The data was subjected to analyze by using Statistix 8.1 software. To test the significance of overall data execute analysis of variance (ANOVA) system and to compare treatment means least significant difference LSD $(P \leq 0.05)$ test was used (Steel et al., 1997).

\section{Results and Discussion}

\section{Germination percentage}

Highly significant changes were found among different tomato cultivars with respect to germination percentage. Cherry Tomato recorded significantly (1.25 fold) highest germination percentage than Lezaforta F1 tomato variety after 12 days (Table 2).

Cocopeat as a growing media in hydroponic system is a best reservoir of plant nutrition and moisture contents because it effects the seed germination, seedling growth and emergence (Grower, 1987; Baiyeri and Mbah, 2006). Moreover, cocopeat media also provide good seedling performance when seedlings are shifted in the hydroponic greenhouse system (Adediran, 2005). According to Bruckner (1997) and Nkongolo and Caron (1999) reported that relative balance between air and water in the pore spaces of growing media is important step for seed germination and plant development. In this study, seedling germination was calculated after four days of sowing in protray. Since cocopeat media were more effective to enhance germination percentage in papaya seedlings compared with media without cocopeat (Bhardwaj, 2014).

Table 2: Response of tomato varieties to different growth parameters.

\begin{tabular}{|c|c|c|c|c|c|c|}
\hline $\begin{array}{l}\text { S. } \\
\text { No }\end{array}$ & $\begin{array}{l}\text { Treat- } \\
\text { ments }\end{array}$ & $\begin{array}{l}\text { Germi- } \\
\text { nation \% }\end{array}$ & $\begin{array}{l}\text { Root } \\
\text { length } \\
(\mathrm{mm})\end{array}$ & $\begin{array}{l}\text { Shoot } \\
\text { length } \\
(\mathrm{mm})\end{array}$ & $\begin{array}{l}\text { Stem } \\
\text { diameter } \\
(\mathrm{mm})\end{array}$ & $\begin{array}{l}\text { No of } \\
\text { leaves }\end{array}$ \\
\hline 1 & Berberana & $95 \mathrm{ab}$ & $37.62 \mathrm{a}$ & $89 a$ & $1.74 \mathrm{a}$ & $6 a$ \\
\hline 2 & Lezaforta & $80 \mathrm{~d}$ & $31.25 \mathrm{~b}$ & $83.75 \mathrm{~b}$ & $1.46 \mathrm{~b}$ & $5 \mathrm{ab}$ \\
\hline 3 & Cherry & $100 \mathrm{a}$ & $32.12 \mathrm{~b}$ & $79.62 \mathrm{c}$ & $0.75 \mathrm{e}$ & $4 \mathrm{~b}$ \\
\hline 4 & $\begin{array}{l}\text { Premium } \\
\text { ruby }\end{array}$ & $89.17 \mathrm{bc}$ & $30.50 \mathrm{~b}$ & $71.87 \mathrm{~d}$ & $1.28 \mathrm{c}$ & $3 c$ \\
\hline 5 & Elipida & $88.33 \mathrm{c}$ & $29.87 \mathrm{~b}$ & $72.12 \mathrm{~d}$ & $1.10 \mathrm{~d}$ & $3 c$ \\
\hline
\end{tabular}

The mean value in the same column followed by different letters are significant when $P \leq 0.05$

\section{Root length}

The root length was one of the influenced growth parameter with different age of seedlings and varieties of tomato. Root length of Berberana tomato variety was increased 1.2 fold higher after 30 days aged seedling as compared to Elipida tomato variety (Table 2). The use of appropriate growing media promotes root growth and plant vigor is important for quality production horticultural crops. Cocopeat is a better growing media serve as a storage for nutrients and water for the plant, allow diffusion of oxygen in root zone and external atmosphere of root substrate which provide adequate support to the plant (Abad et al., 2002). These results are match with the finding of 
Kumar (2007) who found the small changes (6.4$6.59 \mathrm{~cm})$ in the root length of tomato varieties in India. According to Unal (2013) reported that best outcomes regarding tomato seedling root length in M4 (peat-stable manure-perlite) and M5 (peat-sandNPK) media.

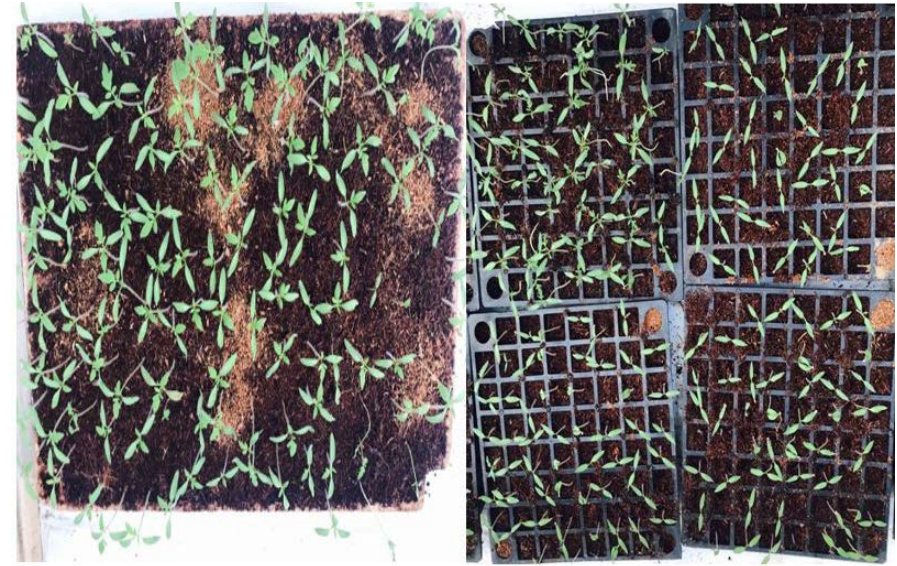

Figure 2: Tomato seedlings germination grown in protray with cocopeat media.

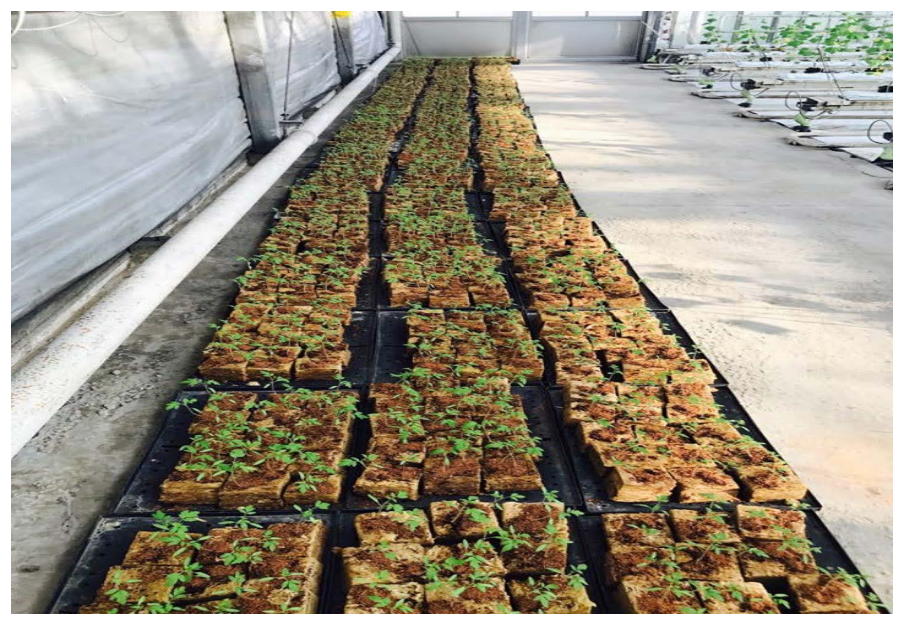

Figure 3: Tomato seedling at transplanting stage.

\section{Shoot length}

The shoot length of Berberana tomato variety was significantly increased by 1.24 fold higher as compared with Premium Ruby tomato variety after 30 days aged seedlings respectively (Table 2). These outcomes are match with the results of Atif et al. (2016) found that equal proportion of compost, peat and traditional practicing media also enhanced tomato shoot length. After 30 days aged seedling higher shoot length were observed in coir pith media (Vivk and Duraisamy, 2017). The increased growth parameters in cocopeat media may be due to higher phosphorous content. Phosphorous is used in the development of high energy compounds, which in return cause several bio-chemical reactions in plant such as adenosine triphosphate and adenosine diphosphate (Memon,
1996). Riaz et al. (2008) reported application of different parameters like diverse growing media on the growth and flowering of zinnia. Therefore, physical and chemical properties of growing media are very critical factor for plant growth and development.

\section{Stem diameter}

The stem girth was also influenced by the age of seedlings according to tomato varieties. It was quite high in 30 days old seedlings having the maximum thickness $(1.74 \mathrm{~mm})$ in Berberana tomato. The minimum stem thickness (0.75) was found in same days of seedling in Cherry Tomato (Table 2). The treatments effect was also significant at 5 per cent level. Related findings were stated by Singh et al. (2007). As plant height was increases automatically the stem thickness was also increased. According to Meena et al. (2017) found that papaya stem girth was recorded higher in vermiculite with $2 \mathrm{~cm}$ cocopeat media because these media supply sufficient nutrients and improves physiological properties and water holding capacity than soil. Stem diameter was significantly showed superior results among different combination of medium used (cocopeat+soil+sand + vermicompost +vermiculite) (1:1:1:1:1) with Azotobacter in acid lime seedling (Yadav et al., 2012).

\section{Number of leaves}

The number of leaves was significantly increased two times in Berberana tomato variety after 30 days old seedlings than Premium ruby and Elipida tomato varieties on same day of seedlings. Age of seedlings and different tomato varieties grown in coco peat media were also significant (Table 2). These consequences are similar with the conclusions of Kumarasinghe et al. (2015) found that cocopeat media is good to increase leaf number per tomato seedling. Higher vegetative growth induced in hydroponics greenhouse system due to more water contents and greater nutrient holding capacity (Wahome et al., 2011). Higher number of leaves was produced due to nutritional contribution of the media. Inden and Torres (2004) reported that utilization of rock wool blocks and perlite media in hydroponics greenhouse system for tomato production provide higher yields than other inert materials.

\section{Conclusions and Recommendations}

Results of the present study indicated that cocopeat media was successfully used for growth and 
germination of tomato seedling. All growth related parameters were significantly $(\mathrm{P} \leq 0.05)$ different among the five tomato varieties evaluated. All tomato varieties perform good in cocopeat media, hence the Cherry and Berberana tomato varieties was found to be good in comparison to other tomato varieties with respect to germination percentage, root length, shoot length, stem diameter and number of leaves.

\section{Author's Contribution}

Mehwish Liaquat: Wrote paper, wrote the abstract, introduction, methodology, result and discussion, conclusion, and references. Arshad Mahmood Malik: Conceived the idea, decide paper title, technical input at every step, overall management of the article. Muhammad Ishaq: Support in research work. Hafiz Muhammad Qasim Ashraf: Data collection, stat analysis, arrange references. Ismara Naseem: Team member.

\section{Conflict of interest}

The authors have declared no conflict of interest.

\section{References}

Abad, M., P. Noguera, R. Puchades, A. Maquieira and V. Noguera. 2002. Physico-chemical and chemical properties of some coconut dusts for use as a peat substitute for containerized ornamental plants. Biores. Technol. 82: 241-245. https://doi.org/10.1016/S09608524(01)00189-4

Adediran, J.A., 2005. Growth of tomato and lettuce seedlings in soilless media. J. Vegetable Sci. 11(1): 5-15. https://doi.org/10.1300/ J484v11n01_02

Atif, M.J., G. Jellani, M.H.A. Malik, N. Saleem, H. Ullah, M.Z. Khanand and S. Ikram. 2016. Different growth media effect the germination and growth of tomato seedlings. Sci. Technol. Dev. 35(3): 123-127. https://doi.org/10.3923/ std.2016.123.127

Baiyeri, K.P and B.N. Mbah. 2006. Effects of soilless and soil-based nursery media on seedling emergence, growth and response to water stress of African breadfruit (Treculia africana Decne). Afr. J. Biotechnol. 5(15): 1405- 1410.

Bhardwaj, R.L., 2014. Effect of growing media on seed germination and seedling growth of papaya cv. 'Red lady'. Afr. J. Plant Sci. 8(4): 178-
184. https://doi.org/10.5897/AJPS11.265

Bruckner, U., 1997. Physical properties of different potting media and substrate mixture especially air and water capacity. Acta Hortic. 450: 263-270. https://doi.org/10.17660/ ActaHortic.1997.450.31

Grower, S.T., 1987. Relations between mineral nutrient availability and fine root biomass in two Costa Rican tropical wet forests. Hypothesis Biotropica. 19(2): 171- 175. https://doi. org/10.2307/2388741

Evans, M.R., S. Konduru and R.H. Stamps. 1996. Source variation in physical and chemical properties of coconut coir dust. Hortic. Sci. 31:965-967. https://doi.org/10.21273/ HORTSCI.31.6.965

Fernandes, A.A., H.E.P. Martinez, D.J. Henriques de Silva, J.G. Barbosa and A.W. Pedrosa. 2007. Successive cultivation of tomato from seeds and vegetative propagation in hydroponic system. Braz. Agric. Res. 42(7): 1013-1019. https://doi. org/10.1590/S0100-204X2007000700014

Ilahy, R., G. Piro, I. Tlili, A. Riachi, R. Sihem, I. Ouerghi, C. Hdider and M.S. Lenucci. 2016. Fractionate analysis of the phytochemical composition and antioxidant activities in advanced breeding lines of high-lycopene tomatoes. Food Funct. 7(1): 574-583. https:// doi.org/10.1039/C5FO00553A

Inden, H. and A. Torres. 2004. Comparison of four substrates on the growth and quality of tomatoe. Acta Hortic. 644: 205-210. https:// doi.org/10.17660/ActaHortic.2004.644.27

Jeong, B.R., 1992. The use of plug transplants in Korea. Division of plant resource and the environment, college of agriculture, Gyeongsang National University, Chinju, Korea. pp. 1-9.

Kumar, S., 2007. Studies on hybrid seed production in tomato (Lycopersicon esculentum Mill.). M.Sc. thesis, Univ. Agric. Sci., India.

Kumarasinghe, H.K.M.S., S. Subasinghe and D. Ransimala. 2015. Effect of cocopeat particle size for the optimum growth of nursery plant of greenhouse vegetables. Trop. Agric. Res. Ext. 18(1): 51-57. https://doi.org/10.4038/tare. v18i1.5324

Meena, A.K., O.P. Garhwal, A.K. Mahawar and S.P. Sing. 2017. Effect of different media on seedling growth parameters and economic of papaya (Carica papaya L) cv. Pusa Delicious. Int. J. Curr. Microbiol. App. Sci. 6(6): 2964-2972. 
https://doi.org/10.20546/ijcmas.2017.606.353

Memon, K.S., 1996. Soil and fertilizer phosphorus. In: Soil Science, Bashir, E. and R. Bantel (Eds.). National Book Foundation, Islamabad. pp. 291316

Nasir,M.U., S. Hussain and S. Jabbar. 2015. Tomato Processing, Lycopene and health benefits: A review. Sci. Lett. 3(1): 1-5.

Nkongolo, N.V. and J. Caron. 1999. Bark particle sizes and the modification of the physical properties of peat substrates. Can. J. Soil Sci. 79: 111-116. https://doi.org/10.4141/S96-084

Perveen, R., H.A.R. Suleria, F.N. Anjum, M.S. Butt, I. Pesha and S. Ahmad. 2015. Tomato (SolanumLycopersicum) carotenoids and lycopenes chemistry: metabolism, absorption, nutrition, and allied health claims: a comprehensive review. Crit. Rev. Food Sci. Nutr. 55(7): 919-929. https://doi.org/10.1080/ 10408398.2012.657809

Prasad, M., 1997. Physical, chemical and biological properties of coir dust. Acta Hortic. 450: 21-29. https://doi.org/10.17660/ ActaHortic.1997.450.1

Qadir, S.A. and H.N. Shahzadi. 1969. Seed germination of common cultivated trees, shrubs and some wild grass. Pak. J. For., 19: 195-22.

Riaz, A., M. Arshad, A. Younis, A. Raza and M. Hameed. 2008. Effect of different growing media on the growth and flowering of Zinnia elegans cv. Blue point. Pak. J. Bot., 40: 15791585.

Singh, B., H.L. Yadav, M. Kumar and N.P.S. Sirohi. 2007. Effect of plastic plug tray cell size and shape on quality of soilless media grown tomato seedling. Acta Hortic. 742: 57 - 60. https://doi. org/10.17660/ActaHortic.2007.742.7

Steel, R.G.D, J.H. Torrie and D.A. Dickey. 1997. Principles and procedures of statistics, a biometrical approach. 3. Boston: McGraw-Hill.
Unal, M., 2013. Effect of organic media on growth of vegetables seedlings. Pak. J. Agric. Sci. 50(3): 517-522.

Vendrame, A.W., I.Maguire and K.K.Moore. 2005. Growth of selected bedding plants as effected by different compost percentages. Florida State Hort. Soc. 18: 368-371

Vinha, A.F., S.V. Barreira, R.C. Alves and M.B. Oliveira. 2014. Organic versus conventional tomatoes: influence on physicochemical parameters, bioactive compounds and sensorial attributes. Food Chem. Toxicol.67(1): 139-144. https://doi.org/10.1016/j.fct.2014.02.018

Vivek, P. and V. M. Duraisamy. 2017. Study of growth parameters and germination on tomato seedlings with different growth media. Int. J. Agric. Sci. Res. 7(3): 461-470. https://doi. org/10.24247/ijasrjun201759

Wahome, P.K., T.O. Oseni, M.T. Masarirambi and V.D. Shongwe. 2011. Effects of different hydroponics systems and growing media on the vegetative growth, yield and cut flower quality of gypsophila (Gypsophila paniculata L). World J. Agric. Sci. 7: 692-698.

Yadav, R.K., M.C. Jain and R.P. Jhakar. 2012. Effect of media on growth and development of acid lime (Citrus aurantifolia Swingle) seedling with or without Azotobacter. Afr.. J. Agric. Res. 7(48): 6421-6426. https://doi.org/10.5897/ AJAR12.1974

Yahya, A., H. Safie and M.S. Mohklas. 1999. Growth and flowering responses of potted chrysanthemum in a coir dust based medium to different rates of slow released fertilizers. J. Trop. Agric. Food Sci. 27: 39-46.

Yau, P.Y. and R.J. Murphy. 2000. Biodegraded cocopeat as a horticultural substrate. Acta Hortic.517:275-278.https://doi.org/10.17660/ ActaHortic.2000.517.33 